Vaccinia virus

\title{
WHO to back vector vaccines
}

\section{Washington}

A SPECIAL advisory group to the World Health Organization (WHO) has approved an accelerated programme of research on recombinant vaccines using viral vectors. Such vaccines, now under development, might be used in mass immunization programmes where alternatives do not exist or are prohibitively expensive. Though yet to be approved by WHO's regular scientific advisory group, the decision puts to rest speculation that the reintroduction of vaccinia immunization programmes might be thought unnecessarily dangerous.

Vaccinia (cowpox virus) has long been a favourite organism for virologists, being easy to culture and safe to handle. With the elimination of smallpox, its use in vaccination was discontinued, because of severe reactions, sometimes fatal, that occur at the rate of 1 or 2 per million vaccinations. Furthermore, vaccinia can be transmitted by skin contact between people and from animals, albeit rarely.

Despite some reservations expressed at a workship held last week jointly by WHO, the US Public Health Service and the British National Institute of Biological Standards and Control, the advisory group decided that the potential benefits of research into recombinant vaccines outweigh

the possible risk. Protection against a number of diseases has already been demonstrated in animals using vaccinia as a vector for antigens, including hepatitis B, herpes simplex virus type 1 and rabies (see for example Nature 311, 67; 1984). Although the safety of these vaccines has not been systematically studied, it appears that deletion of the thymidine kinase gene of vaccinia - which is replaced by the foreign gene - may make the virus even less easily transmitted than the normal type.

In its advice to WHO, the advisory group stresses the importance of developing alternative vectors likely to be of use against diseases of the respiratory tract and enteric diseases, including bacterial, protozoal and helminthic diseases. Because much early experience will be with animal vaccines, WHO is urged to establish links with the United Nations Food and Agriculture Organization to monitor veterinary results. And to avoid countries using different strains of vaccines haphazardly, WHO is invited to set up a collaborative centre for dissemination of information and storage of reference samples, probably to be located at the National Institute for Allergy and Infectious diseases at Bethesda, Maryland.

Tim Beardsley

\section{Israeli education}

\section{Palestinians push ahead}

\section{Rehovot}

THE latest of Israel's institutions of higher learning, Ben-Gurion University of the Negev, has finally begun its academic year, two weeks behind schedule. It remains to be seen, however, how long Ben-Gurion and the others - all plagued by severe financial problems - will remain open.

To be sure, Ben-Gurion University, with an accumulated debt of US \$15 million, is worse off than the older, better established institutions. And this presumably explains both the delayed opening and the resignation (later withdrawn) of university president Shlomo Gazit. But with government support for higher education having dropped by one-third in recent years, the other schools are not in much better shape. The president of the Haifa Technion, Professor Josef Singer, has stated that "the Technion is still $\$ 10$ million short of even its reduced emergency budget and the conditions for an uninterrupted school year have not yet been guaranteed"'.

There is greater sympathy for the plight of the universities among members of the present government than existed in the last one, and education minister Yitzhak Navon, for one, has described their situation as "intolerable". But with all public spending being drastically reduced, including substantial cutbacks in even defence and social welfare, it is unlikely that the government will be more generous than it has been in the past: in all probability, support will decline still further. This has forced the universities not only to undertake large-scale dismissals and reduce their purchases of vital scientific equipment, but also to shut down whole departments.

This development is taking place against the background of a dramatic increase in the educational level of Palestinians, both in Jordan and in the West Bank. During the 1983-84 academic year, 25,000 Jordanians and 13,000 West Bank Arabs passed the Jordanian matriculation examinations, about twice the number of matriculants as among the Jews of Israel, from roughly the same population of some four million people.

Educational advancement has been particularly specatular in the territories under Israeli control since 1967. From 1967 to 1982 , the secondary school population in the West Bank and the Gaza Strip increased by 106 per cent, while the general population went up only 23 per cent; and while in 1967 there were just a few hundred students in post-secondary programmes in those two areas, this year there will be nearly 20,000 , a very high proportion.

Nechemia Meyers

\section{Gromyko's prize}

THIS year's Soviet State Prizes for science, announced as usual to coincide with the anniversary of the 1917 October Revolution - in November - went almost entirely to "cycles of works" carried out by teams of up to 12 persons over a long period of time. Only four prizes of the fourteen went to monographs by a single author: Ilya N. Vekua's "Some general methods of constructing different variants of the theory of shells"'(1982), Dr Andrei D. Ado's “General allergology” (1978), Dr Valentin V. Seldov's "The East Slavs in the sixth to thirteenth centuries" (1982) and foreign minister Andrei A. Gromyko's "External expansion of capital: past and present"' (1982).

Several of the "cycles" honoured cover two decades or more including B.B. Bokut' et al.'s "Highly effective nonlinear transformations of frequency in crystals and the creation of returnable sources of coherent optical radiation"' (1963-82), I.N. Matrosov et al.'s "Elaboration of the method of Lyapunov vector functions for the analysis of stability and other dynamic properties of nonlinear systems"' (1962-81) and K. P. Belov et al. "Magnetism and the electronic structure of rare-earth and uranium compounds" (1959-82), One citation seems to have been overdue - that of N. N. Bogolyubov, D. V. Shirkov and A. A. Logunov for their contribution "Method of renormalized groups in field theory", which carries the date 1955-56.

The citations do not make it clear just how far a cycle of work consists of genuine collaborative undertakings and how far it relates to parallel but separate work on a common theme. Co-winners are frequently scattered throughout several institutes, and even republics. Thus Bokut' et al. come from Gomel' University (Byelorussia), the Vavilov State Optical Institute, Moscow State University, the Institute of General Physics of the Soviet Academy of Sciences, Vilnyus State University (Lithuania), the Institute of Electronics of the Uzbek Academy of Sciences and the Institute of Applied Physics of the Soviet Academy of Sciences. On the other hand, the team of geologists honoured for their complex study of the Baltic regions of the Soviet Union were all, to judge from their names, native to the Baltic republics (Latvia, Lithuania and Estonia) and for the most part are employed in research institutions of those republics, although one holds an all-Union post, as deputy director of the Marine Scientific Research Association of Engineering Geology. Likewise the team responsible for "Development of the theoretical principles of Soviet criminology" (1961-82) - a unusual subject for a state prize - all seem to be Moscow-based, although affiliated to such diverse institutions as the Academy's Institute of State and Law and the Moscow Police College. Vera Rich 